University of Nebraska - Lincoln

DigitalCommons@University of Nebraska - Lincoln

2006

\title{
Insect Visitation and Pollen Deposition in an Invaded Prairie Plant Community
}

Diane L. Larson

USGS Northern Prairie Wildlife Research Center, dlarson@usgs.gov

Ronald A. Royer

Minot State University

Margaret R. Royer

Minot State University

Follow this and additional works at: https://digitalcommons.unl.edu/usgsnpwrc

Part of the Other International and Area Studies Commons

Larson, Diane L.; Royer, Ronald A.; and Royer, Margaret R., "Insect Visitation and Pollen Deposition in an Invaded Prairie Plant Community" (2006). USGS Northern Prairie Wildlife Research Center. 85.

https://digitalcommons.unl.edu/usgsnpwrc/85

This Article is brought to you for free and open access by the US Geological Survey at DigitalCommons@University of Nebraska - Lincoln. It has been accepted for inclusion in USGS Northern Prairie Wildlife Research Center by an authorized administrator of DigitalCommons@University of Nebraska - Lincoln. 


\title{
Insect visitation and pollen deposition in an invaded prairie plant community
}

\author{
Diane L. Larson ${ }^{a, *}$, Ronald A. Royer ${ }^{b}$, Margaret R. Royer ${ }^{b}$ \\ ${ }^{a}$ USGS Northern Prairie Wildlife Research Center, 100 Ecology Building, 1987 Upper Buford Circle, St. Paul, MN 55108, United States \\ ${ }^{\mathrm{b}}$ Division of Science, Minot State University, Minot, ND, United States
}

\section{A R T I C L E I N F O}

Article history:

Received 15 July 2005

Received in revised form

28 November 2005

Accepted 14 December 2005

Available online 26 January 2006

\section{Keywords:}

Biological invasion

Euphorbia esula

Halictidae

Mixed-grass prairie

Pollen on stigmas

\begin{abstract}
A B S T R A C T
Invasive plants with large flowering displays have been shown to compete with native plants for pollinator services, often to the detriment of native plant fitness. In this study, we compare the pollinator communities and pollen deposited on stigmas of native plant species within and away from stands of the invasive alien plant, leafy spurge (Euphorbia esula) at a large natural area in North Dakota, USA. Specifically, we ask if infestation influences (1) visitation rates and taxonomic composition of visitors to native flowers, and (2) the amount of conspecific pollen, number of pollen species, and proportion of heterospecific pollen on stigmas of native plants. We observed visits to selected native species during May and June 2000 and 2001. Stigmas were collected from a subsample of the flowers within these plots, squashed, and the pollen identified and counted under a light microscope. Visitation varied between years and among species of native plants: infestation had mixed effects in 2000 but visitation, especially by halictids was always lower within infestations in 2001. Despite differences in visitation between years, we found significantly less conspecific pollen on stigmas from infested plots in six of eight cases; we never found significantly more conspecific pollen on stigmas from within infestations. Our results emphasize the temporal variability in plant-pollinator relations and the added complexity imposed by an invasive species that will always make prediction of effects difficult. Nonetheless, the consistently lower conspecific pollen counts on native stigmas within infestations, regardless of visitation, suggest the likelihood of negative effects.
\end{abstract}

(c) 2005 Elsevier Ltd. All rights reserved.

\section{Introduction}

Many alien plants form dense monospecific stands that flower profusely, and thus may introduce substantial amounts of alien pollen and nectar into the native communities they invade. The diffuse nature of pollination mutualisms (Palmer et al., 2003) and the multiple interspecific interactions involved (Waser et al., 1996) make the outcome of such an influx of resources highly uncertain. If an increase in resources attracts a disproportionately larger number of pollinators to the area, pollination of native plants in the vicinity of the infestation could be enhanced (Feldman et al., 2004); however, if those pollinators preferentially visit the invasive species, visitation to, and therefore pollination of, native plants could be depressed (Rathcke, 1983). Because pollination systems tend to be generalized, especially in the northern temperate zone of North America (Johnson and Steiner, 2000), pollination of native plants also could be depressed if pollinators that visit native plants deposit alien pollen on their stigmas, and much of the native pollen is carried to aliens, rather than to conspecifics (improper pollen transfer (IPT); Waser, 1978; Rathcke, 1983). Alien pollen that makes its way to native plant

\footnotetext{
* Corresponding author: Tel.: +1 612625 9271; fax: +1 6126246777 .
}

E-mail address: dlarson@usgs.gov (D.L. Larson). 
stigmas may affect reproduction by clogging or mechanically blocking the stigma or style, by chemically interfering with fertilization (allelopathy), or by producing hybrids (Brown and Mitchell, 2001; McLernon et al., 1996; Waser, 1978).

Indeed, evidence has begun to accumulate that suggests invasive plants with large flowering displays can compete with native plants for pollinator services, often to the detriment of native plant fitness. Effects have been documented in terms of both pollen quantity and quality (Brown and Mitchell, 2001; Brown et al., 2002; Chittka and Schürkens, 2001; Moragues and Traveset, 2005). What is not yet clear is whether the change in pollination success is due to the change in the prevalence of exotic pollen, which is dispersed (at the expense of native pollen) by the same generalist pollinator community that existed prior to infestation, a change in the pollinator community that visits native plants to fewer or less efficient pollinators, a change in rates of visitation to flowers, or some combination of these. If plants compete for pollinator services, a new plant species that provides copious resources will dramatically alter the competitive relationships within the plant community, with less abundant species being put at a distinct disadvantage (Palmer et al., 2003), especially with respect to constant pollinators that specialize on abundant and rewarding flowers (e.g., Gegear and Laverty, 1998, 2004; Kunin, 1993). In contrast, if pollinators compete for floral rewards, introduction of a super-abundant resource may mean that pollen and nectar are no longer limiting, and new or formerly out-competed insect taxa may enter the system. These issues are of concern not only with respect to potential effects on pollen-limited plants, but also in light of recent indications of declining pollinator populations (Kearns et al., 1998; Spira, 2001).

In this study, we compare the pollinator insect communities and pollen delivered to stigmas of native plant species within and $>100 \mathrm{~m}$ away from stands of the invasive alien plant, leafy spurge (Euphorbia esula L.; Euphorbiaceae; hereafter Euphorbia). Specifically, we ask (1) does visitation to native flowers by pollinator insect taxa vary between infested and non-infested sites, (2) does the amount of conspecific pollen on stigmas vary between infested and non-infested sites, and (3) does infestation influence the number of pollen species and proportion of heterospecific pollen on native plant stigmas? If the presence of Euphorbia facilitates pollination of native species, we would expect more visitation and greater amounts of conspecific pollen on stigmas of native flowers in infested sites compared with non-infested sites. On the other hand, if Euphorbia competes with native species for pollinators, we would expect fewer visits and less conspecific pollen on native stigmas in infested sites. Less conspecific pollen on native stigmas could also result from a change in the pollinator community within infested sites to species that are less constant in visitation habit; if this is the case, we would expect to find a higher diversity of pollen species on stigmas in infested sites.

\section{Methods}

\subsection{Study site}

The study was conducted in the South Unit of Theodore Roosevelt National Park (TRNP) in western North Dakota, USA.
Vegetation at the park is dominated by native cool season grasses, primarily Pascopyrum smithii and Stipa spp. The south unit of the park was established in 1947 and contains freeranging native ungulates as well as a small herd of wild horses. More detail on plant species associations within the park can be found in Larson et al. (2001). E. esula was first documented in the South Unit of TRNP in 1970 (unpublished park documents). Infested and non-infested areas used in this study had been so since at least 1996.

Euphorbia esula is a Eurasian perennial that invades mixedgrass prairie in rangeland and natural areas throughout the northern Great Plains and causes extensive environmental and economic damage (Bangsund et al., 1996, 1999; Trammell and Butler, 1995). Aerial photography in 1991 indicated approximately 1620 ha of Euphorbia in the South Unit of TRNP, with the distribution closely aligned with watercourses and drainages. Euphorbia flowers profusely during June in North Dakota, bearing terminal umbels with sequentially maturing female and male flowers (cyathia); each "wave" of flowers produces 5-12 female followed by 11-20 male flowers and each stem may branch to produce as many as 16 umbels (Selleck et al., 1962). Each plant's yellow flowers mature in succession over a period of several weeks. Pollen remains viable for up to 2 days on each flower and nectar is produced by the glands of the cyathium 3-8 days after inversion of the female flower (Selleck et al., 1962), so a consistent source of pollen and nectar remains available for approximately 6 weeks at our study sites. Capsules, which are explosively dehiscent, mature in mid- to late-summer and contain up to three seeds.

\subsection{Sampling design}

Using data from a 1996 stratified-random survey of plants in the South Unit in which $>800$ geo-referenced transects were examined (methods for the survey can be found in Larson et al. (2001)), we identified areas within the South Unit that were likely to have one of several concurrently blooming native plants, either $>100 \mathrm{~m}$ away from or within a Euphorbia infestation. We avoided the dwarf sagebrush (Artemesia cana) and river bottom vegetation types because they harbor large populations of a variety of non-native species (Larson et al., 2001). All sampling was done in upland prairie to minimize bias in insect habitat characteristics that could be associated with infested versus non-infested habitats. For an area to be considered infested, it had to have flowering Euphorbia stems intermixed with flowering native species; total area of each infestation varied from tens of square meters to a hectare or more. In consideration of the necessary sample size, only relatively common species were selected as target native species. We narrowed our target native species to only those that, upon field inspection, occurred both within and at least $100 \mathrm{~m}$ away from an infestation and that bloomed concurrently with Euphorbia. While $100 \mathrm{~m}$ is admittedly arbitrary, it was the largest area we could reasonably search exhaustively for the presence of Euphorbia. Our goal was to minimize the chance that insects that had visited Euphorbia would arrive at our non-infested plots. Target native species in 2000 were Campanula rotundifolia L. (Campanulaceae) for visitation only and Linum lewisii Pursh var. lewisii (Linaceae) and Oxytropis lambertii Pursh var. lambertii (Fabaceae) for pollen counts and 
visitation. In 2001 we added Calylophus serrulatus (Nutt.) Raven (Onagraceae), Sphaeralcea coccinea (Nutt.) Rydb. ssp. coccinea (Malvaceae), and Vicia americana Muhl. ex Willd. (Fabaceae) for pollen counts (we were unable to obtain a sufficient sample size to analyze visitation to these species), and conducted pollen counts on Campanula. Of these, Linum, Campanula, Calylophus and Sphaeralcea as well as Euphorbia have actinomorphic (i.e., radially symmetrical) flowers, although Campanula is bell-shaped and must be entered from below, and Oxytropis and Vicia have zygomorphic (i.e., bilaterally symmetrical). Taxonomy follows the USDA Plants data base (USDA 2004). We use the genus name to refer to these species throughout the paper.

\subsection{Visitation}

We assessed visitation to native flowers and to those of Euphorbia within $1 \mathrm{~m}^{2}$ square plots that contained at least six (total) individual flowering stems of one or more of the native target species. Plots were located in the vicinity of one of the survey transects (described above) where a target species occurred and were positioned so that the required number of target species was included in the plot. We counted the number of flowers of each target species, Euphorbia inflorescences, and any other species in flower within the plot. In addition, we counted the number of flowers by species in six $0.25 \times 0.25 \mathrm{~m}$ quadrats in each of the four cardinal compass directions outside the plot, since flower density may influence visitation and our plots might not adequately reflect density at the scale perceived by pollinators. Visitation on most plots was assessed once in the morning and once mid-day, weather permitting; results were averaged for each plot prior to analysis. Different plots were established each day.

Observations lasted $20 \mathrm{~min}$, during which time each pollination event on each target flower was recorded on a data sheet. We defined a pollination event (hereafter termed "visit") as any contact of an insect with anthers or stigmas on an individual flower. We recorded the flower species visited and the insect to the lowest field-identifiable taxonomic category (see below). At the end of the 20-min period, a new plot was established in a new location and the process repeated. Observations were made between 07:00 and 14:30 (most after 08:00) with temperatures between 14 and $35^{\circ} \mathrm{C}$. We did not conduct observations if winds were in excess of Beaufort 4 (5-6 knots) or if it was raining. We assessed insect visitation on 233 plots $(77.67 \mathrm{~h}$ at $20 \mathrm{~min} / \mathrm{plot})$ over the two year period and recorded 763 individual insect visits in 2000 and 812 in 2001.

A haphazard sample of bees was collected at each area where visitation was assessed during the 2000 field season and sent to a taxonomic expert for identification. Observers were trained to identify common bee families prior to beginning work. They were often able to distinguish Bombus, Apis, Halictus, Dialictus, Agapostemon and Lasioglossum, but native bees could not be identified to species in the field. We did not distinguish among taxa of wasps because we could not reliably discern taxa in the field, or lepidopterans because visitation rates were low enough that individual taxa could not be analyzed statistically. Flies were overwhelmingly muscoid, and taxa were not separated for analysis.

\subsection{Pollen loads on stigmas}

Prior to beginning observations (described above), four flowers of the target species in each plot were chosen arbitrarily and marked with a small bit of pastel-colored thread, each a different color. The thread did not appear to influence pollinators; none investigated the thread and marked flowers were no more likely to be visited than unmarked flowers (data not shown). After observations were completed for that day, we collected stigmas of the four marked flowers in each plot and placed them individually in glassine envelopes. Upon returning to the lab, stigmas were placed on microscope slides with a drop of resin-based mounting medium. The cover slip was pressed firmly over the stigma to squash it and force the pollen into a single layer, suitable for counting (Kearns and Inouye, 1993).

We made a reference pollen collection of all flowering plants in the vicinity of our plots. We did not collect grass pollen, however, which may account for some of the pollen grains we were unable to identify. Prior to counting pollen on collected stigmas, counters familiarized themselves with the reference collection by hand drawing and measuring pollen from each collected species. Pollen on stigmas was identified and counted by visually scanning the entire slide, since squashing the stigma spread the pollen out away from it. When a pollen grain could not be identified using the reference collection or other resources available to us, it was given a unique ID that we used to classify other grains on other slides. Each of three counters kept their own list of unknowns, which we did not try to reconcile, so the number of unknown species is inflated. Stigmas from 653 flowers were evaluated for pollen loads. In all, we counted 175,507 pollen grains divided among 23 identified pollen species and 6192 pollen grains divided among 38 unknown pollen morphotypes; approximately $3 \%$ of pollen grains counted were of unknown species.

\subsection{Statistical analysis}

We used mixed models with type III sums of squares (PROC MIXED; SAS 8.02 (SAS Institute, 1999)) to identify differences in visitation rates to native plant species in plots in Euphorbia-infested sites and in sites $>100 \mathrm{~m}$ from an infestation. Dependent variables were number of visits to flowers of native species, which were analyzed separately; independent variables included visitor taxon, infestation, year and all possible interactions. Plot was the random variable nested within infestation. A parallel analysis was conducted with genus within the Halictidae replacing visitor taxon as an independent variable for 2001 only. The abundance of flowering conspecifics and other plant species within and adjacent to the visitation plot were used as covariates to control for differences in flower abundance among plots; the number of individuals of other species was never statistically significant and was excluded from analyses presented in this paper.

We also used mixed models to determine the effect of infestation on (1) number of conspecific pollen grains, (2) number of leafy spurge pollen grains, (3) number of pollen species, and (4) proportion of heterospecific pollen on stigmas of each native species. Because we had two years of data for 
Linum and Oxytropis, we ran one analysis with infestation, stigma species, year and all possible interactions as independent variables for these two species. A second analysis, for 2001 only, used all species sampled in that year, with infestation, stigma species and their interaction as independent variables. Total number of conspecific flowers within and adjacent to the plot was used as a covariate to separate effects of flower abundance from effects of infestation on conspecific pollen. All quantitative variables with the exception of proportion of heterospecific pollen were log transformed (after adding 1) to improve normality. Proportion of heterospecific pollen was square-root transformed prior to analysis, also to improve normality.

\section{Results}

Plots contained $1.1 \pm 0.04$ flowering species (mean $\pm \mathrm{SE}$ ) in non-infested areas and $1.9 \pm 0.03$ (mean $\pm \mathrm{SE}$ ) in infested areas $(F=303.87, \mathrm{df}=1,427, p<0.0001)$; the higher number of species within infestations is attributable to the presence of Euphorbia in plots. Of 299 observations of insects moving between flowers within a plot, only 8 involved $>1$ species. The number of conspecific target flowers (other than leafy spurge) in a plot averaged $15.4 \pm 0.86$ in non-infested areas and $11.0 \pm 0.65$ in infested areas, a significant difference ( $F=16.41, \mathrm{df}=1,427, p<0.0001)$; total flowers in the plots (including Euphorbia) did not vary between non-infested and infested plots $(15.4 \pm 1.1$ and $17.5 \pm 0.8$, respectively, $F=2.36$, $\mathrm{df}=1,427, p=.1252)$. Plots in infested areas averaged $6.4 \pm 7.0$ leafy spurge stems.

\subsection{Visitation}

Native species in infested plots received $89 \%$ as many visits as in non-infested plots in 2000. In contrast, in 2001 native species in infested plots received only $57 \%$ as many total visits as did those in non-infested plots $(F=3.93, \mathrm{df}=1,82, p=0.05$ for the infestation by year interaction). Significantly more bees visited Linum in non-infested than infested sites in 2001, but not 2000 when visitation was similar between infestation levels (Fig. 1 and Table 1; least square means and standard errors for all visitation analyses are included in Appendix A). Bees and flies were the most common visitors to Linum. Like Linum, Campanula received more visits by bees in non-infested than in infested areas in 2001, but the reverse was true in 2000, when more visits were recorded in infested than in non-infested areas (Fig. 1). Flies were more common visitors to all native plant species in 2001 than in 2000. We recorded no visits by Lepidoptera or wasps to Campanula, and few by Bombus. Unlike Linum and Campanula, infestation by Euphorbia did not significantly influence visitation to Oxytropis (Fig. 1). The significant insect taxon by year interaction (Table 1) reflected strong shifts in visitation by Bombus, flies and Lepidoptera to Oxytropis between years. In contrast to the native species, we found no significant differences in visitation to Euphorbia itself between years (Table 1); flies were by far the most common visitors in both years (Fig. 1).

We also examined visitation by native bee taxa, other than Bombus, we could identify in the field, including the genera Dialictus, Halictus, Agapostemon and Lasioglossum in the family
Halictidae. This analysis was restricted to 2001, when we had more confidence in our identification of the bees. Halictids in the four genera above comprised $66 \%$ of our observations of bees in 2001, with the remainder made up of apids (Apis mellifera, the only exotic bee encountered, was recorded in only six plots), andrenids, megachilids and unidentified halictids (based on the sample identified in 2000; see Section 2); trends in the unknown bees collectively followed those of the halictids. Overall, we recorded nearly three times as many visits by halictids in non-infested sites as we did in infested sites $(0.96 \pm 0.08$ and $0.33 \pm 0.06$, ln-transformed least square mean \pm SE, respectively) in 2001. Visits to Linum varied with both bee taxon and infestation, but there was no interaction between the variables (Fig. 2 and Table 2). There were fewer visits by halictids of all taxa within infested sites than in non-infested sites. Dialictus and Halictus were the most common genera of bees to visit Linum. Visits by halictids to Campanula were also significantly reduced in sites infested by Euphorbia. Dialictus spp. tended to be the most common visitors to Campanula, but the differences among bee taxa were not statistically significant. Oxytropis had a non-significant trend toward higher visitation by halictids in non-infested sites, but there were no differences among taxa. Euphorbia itself was more commonly visited by Dialictus spp. than other bee taxa.

\subsection{Pollen loads on stigmas}

The amount of conspecific pollen on stigmas of Linum and Oxytropis was greater in the absence of Euphorbia than within an infestation (Table 3), and this did not vary between 2000 and 2001 (Table 4). Very little Euphorbia pollen was found on these two native species and this did not vary significantly with infestation or species. Suggestive of preferences of generalist pollinators for Linum, we found more pollen species and a larger proportion of heterospecific pollen on Linum than on Oxytropis stigmas (Table 3), and this was not influenced by infestation and did not vary between 2000 and 2001 (Table 4).

Looking only at 2001, but including all six species sampled that year, similar patterns emerge. The presence of Euphorbia within $100 \mathrm{~m}$ was significantly associated with fewer conspecific pollen grains on stigmas of native species (Fig. 3 and Table 5). The small amount of Euphorbia pollen we found on native stigmas was marginally greater in infested than in non-infested sites (Fig. 3 and Table 5). Two species, Calylophus and Vicia, had no Euphorbia pollen at all and could not be included in the analysis. The fact that we encountered Euphorbia pollen in non-infested sites implies that the pollen moved $>100 \mathrm{~m}$, at least in a few cases. Overall, 65 of the 653 flowers examined had Euphorbia pollen on at least one of their stigmas; 13 of these were collected in non-infested sites and 42 in infested sites. We found fewer pollen species on stigmas of native plants in infested than in non-infested sites but the proportion of heterospecific pollen on stigmas was greater for most species in infested than in non-infested sites (Fig. 3). Linum was an exception to this trend, with a larger proportion of heterospecific pollen in non-infested sites in 2001. Campanula and Sphaeralcea were most likely to have several pollen species on their stigmas while Vicia never and Oxytropis very rarely had pollen from other species on their stigmas. 
a. Visits by pollinators $2000-2001$

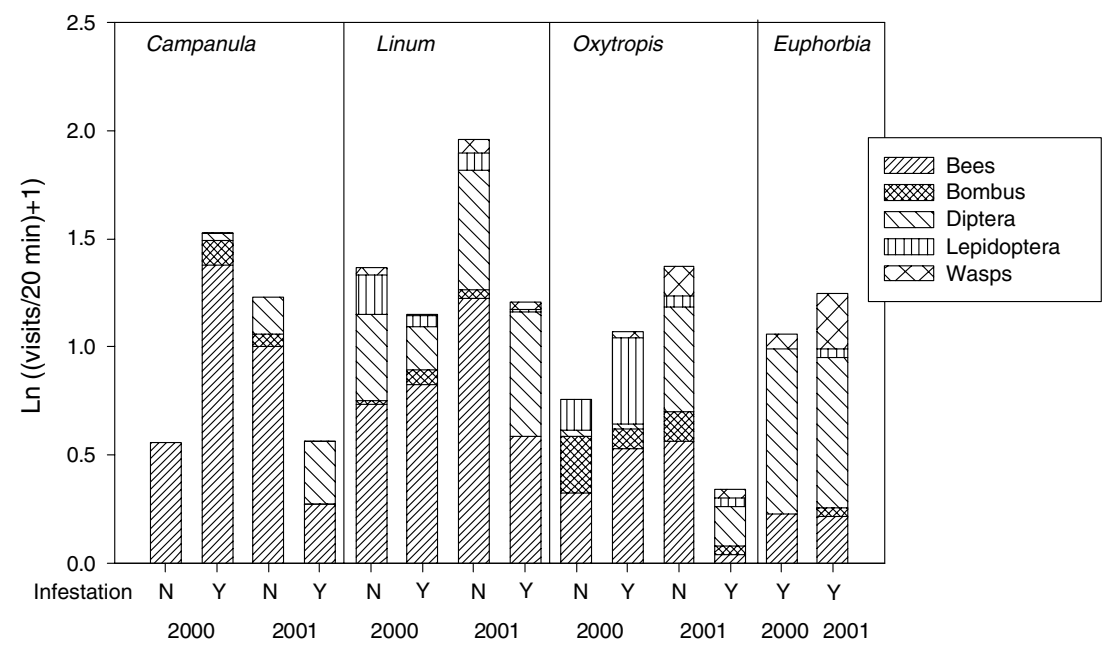

b. Visits by halictid bees, 2001

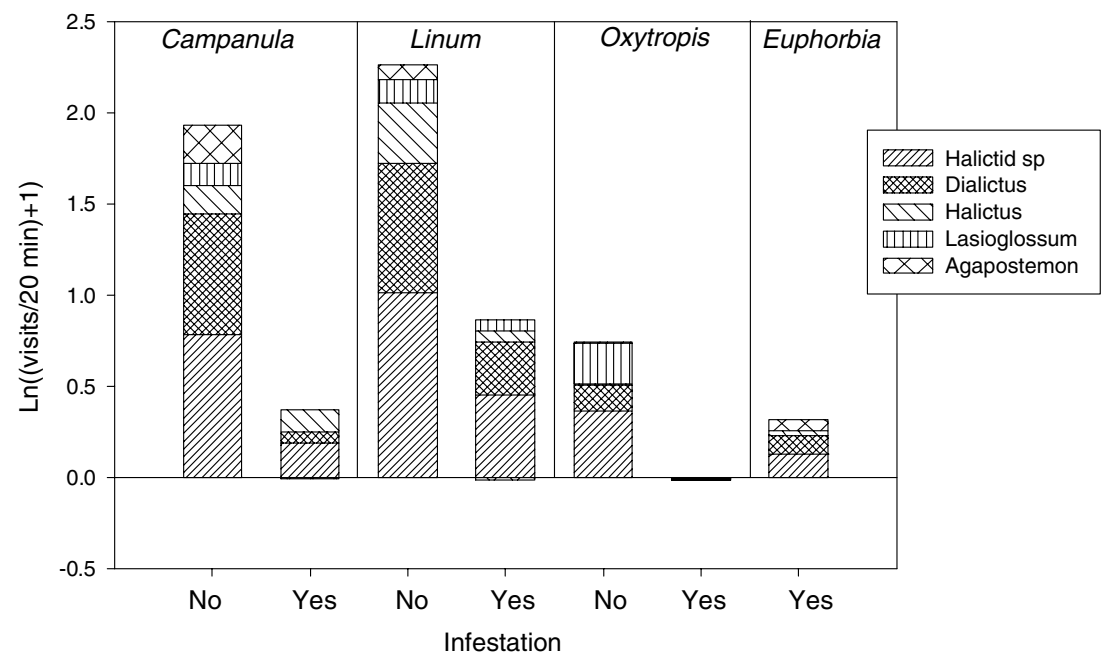

Fig. 1 - Cumulative visitation by pollinator taxa to native species and Euphorbia. (a) Visitation by all taxa in 2000-2001; (b) visitation by halictid bees in 2001.

\section{Discussion}

\subsection{Visitation and conspecific pollen}

The relationship between Euphorbia infestation and pollination of native plants at our study sites was not as straight-forward as our hypotheses implied it would be. Although both visitation and deposition of conspecific pollen were lower on infested plots in most cases, this varied both by plant species and between the two years of the study. Year-to-year variation in pollination studies is to be expected: the variability inherent in pollination systems is well documented and many have warned of the difficulties in interpreting shortterm studies (Fishbein and Venable, 1996; Herrera, 1988, 1995; Price et al., 2005; Roubik, 2001). Although we found clear effects of infestation on visitation by bees in 2001, results were more variable for 2000 , when visits to Campanula were higher in infested than non-infested sites and visits to Oxytropis and Linum did not differ significantly with infestation.
Moragues and Traveset (2005) examined effects of the invasive Carpobrotus on several native species on an island in the Mediterranean and found similar variability in effects between years. Although, like Moragues and Traveset (2005), we found greater levels of visitation in infested plots for one species (Campanula) in one year, the lack of increased conspecific pollen on stigmas of Campanula suggests that we did not observe facilitation. Our results show that effects of infestation on insect visitation exist, but do not give an indication of how consistently they are expressed. Nonetheless, we never found significantly greater amounts of conspecific pollen on stigmas from infested areas and, in six of eight cases, the amount of conspecific pollen was significantly less on stigmas from infested areas.

Visitation and the amount of conspecific pollen on stigmas were not correlated in our study. Mean amount of conspecific pollen on Linum stigmas from non-infested plots did not vary between years even though overall visitation was much higher on non-infested plots in 2001 than 2000. Further, despite 
Table 1 - ANOVA results for visitation by insects to Linum lewisii, Campanula rotundifolia, Oxytropis lambertii and Euphorbia esula in 2000-2001

\begin{tabular}{|c|c|c|c|c|c|}
\hline Target species & Effect & Num. DF & Den. DF & F value & $\operatorname{Pr}>F$ \\
\hline \multirow[t]{8}{*}{ L. lewisii } & Infestation & 1 & 100 & 4.95 & 0.0283 \\
\hline & Insect taxa & 4 & 404 & 56.72 & $<0.0001$ \\
\hline & Year & 1 & 404 & 1.92 & 0.1663 \\
\hline & Infestation $\times$ taxa & 4 & 404 & 1.24 & 0.2938 \\
\hline & Infestation $\times$ year & 1 & 404 & 1.62 & 0.2043 \\
\hline & Taxa $\times$ year & 4 & 404 & 2.15 & 0.0741 \\
\hline & Infestation $\times$ taxa $\times$ year & 4 & 404 & 3.75 & 0.0053 \\
\hline & Covariate & 1 & 404 & 16.23 & $<0.0001$ \\
\hline \multirow[t]{8}{*}{ C. rotundifolia } & Infestation & 1 & 33 & 0.21 & 0.6522 \\
\hline & Insect taxa & 4 & 131 & 24.84 & $<0.0001$ \\
\hline & Year & 1 & 131 & 0.19 & 0.6664 \\
\hline & Infestation $\times$ taxa & 4 & 131 & 0.05 & 0.9947 \\
\hline & Infestation $\times$ year & 1 & 131 & 6.21 & 0.0139 \\
\hline & Taxa $\times$ year & 4 & 131 & 2.01 & 0.0962 \\
\hline & Infestation $\times$ taxa $\times$ year & 4 & 131 & 6.18 & 0.0001 \\
\hline & Covariate & 1 & 131 & 0 & 0.9594 \\
\hline \multirow[t]{8}{*}{ O. lambertii } & Infestation & 1 & 42 & 0.8 & 0.3763 \\
\hline & Insect taxa & 4 & 172 & 3.26 & 0.0132 \\
\hline & Year & 1 & 172 & 0.01 & 0.9362 \\
\hline & Infestation $\times$ taxa & 4 & 172 & 0.87 & 0.4808 \\
\hline & Infestation $\times$ year & 1 & 172 & 3.3 & 0.0709 \\
\hline & Taxa $\times$ year & 4 & 172 & 2.55 & 0.0411 \\
\hline & Infestation $\times$ taxa $\times$ year & 4 & 172 & 1.22 & 0.3032 \\
\hline & Covariate & 1 & 172 & 9.48 & 0.0024 \\
\hline \multirow[t]{4}{*}{ E. esula } & Year & 1 & 348 & 0.95 & 0.3311 \\
\hline & Insect taxa & 4 & 348 & 34.76 & $<0.0001$ \\
\hline & Year $\times$ taxa & 4 & 348 & 0.95 & 0.4353 \\
\hline & Covariate & 1 & 348 & 16.3 & $<0.0001$ \\
\hline
\end{tabular}

The covariate is the number of flowers of the target species within the plot.

similar visitation rates between infested and non-infested plots in 2000 for both Linum and Oxytropis, conspecific pollen numbers were still lower on stigmas from infested plots. These observations imply that not only does the quantity of pollinators vary among years, but perhaps more importantly, so does the quality: more visitation does not always mean more conspecific pollen. Lau and Galloway (2004), studying the effects of low-efficiency, or "ugly", pollinators on male function in Campanula americana, cautioned that increased visitation rates cannot be assumed to translate directly to increased fitness.

Having ruled out facilitation, does Euphorbia compete with native species for pollinators? Although lower levels of visitation and less conspecific pollen within infestations suggest competition, the observational nature of this study and our level of taxonomic resolution do not allow a definitive answer. However, the prevalence and consistency of Diptera in the pollinator assemblage of Euphorbia, compared with the prevalence of bees in that of the native species, suggests that, unlike the congeners Lythrum salicaria and L. alatum (Brown and Mitchell, 2001), these native plants may be experiencing relatively little competition for pollinator services with the invasive. Memmott and Waser (2002) demonstrated via food-web analyses that invasive plant species have become integrated into the interaction webs of the pollinator communities they studied. However, they found that alien plants were mainly pollinated by generalists. Results of our study agree, in that flies were the primary visitors to Euphorbia. Although bees were observed to visit Euphorbia, the magnitude of this visitation did not, on average, balance the deficit seen in visitation to natives in infested sites.

Flies did make a substantial contribution to the pollinator community of one native species, Linum, and they have been shown to effectively pollinate this species in other locations (Kearns and Inouye, 1994). Flies were marginally less common visitors to Linum in infested than non-infested plots in 2000 , leaving open the possibility that Euphorbia was attracting pollinators from Linum in this year. Note that in 2001, when flies visited all species relatively frequently, there was no effect of infestation on fly visits to Linum. Thus, effects of infestation likely depend on the population size of pollinators in a given year.

Visitation by pollinators is known to be strongly influenced by flower density (Kunin, 1997). We statistically accounted for differences in native flower density between infested and non-infested plots in this study, yet still found a significant effect of infestation on conspecific pollen deposition. The native species we targeted were common and pollen was still sufficiently abundant to fertilize all the ovules (but see Mitchell (1997)). However, the combined effects of low density and less conspecific pollen transported 
a. Conspecific pollen grains/stigma

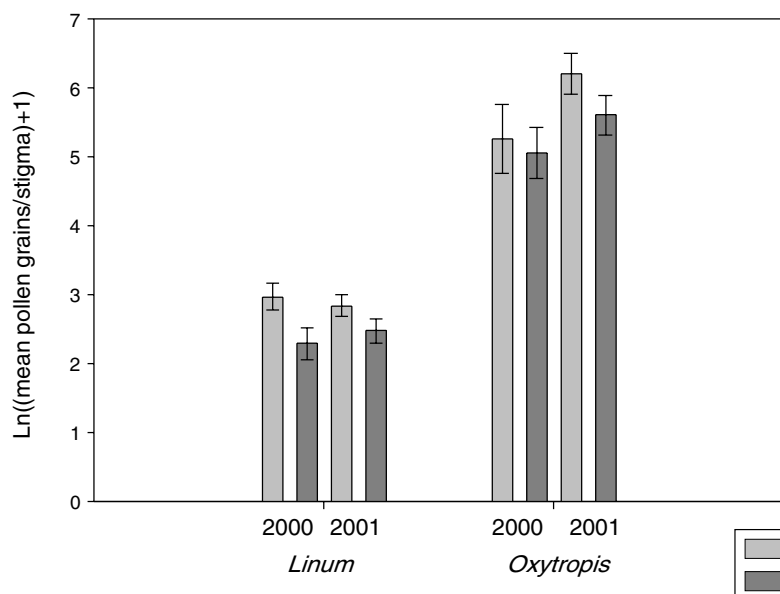

C. Number of pollen species/stigma

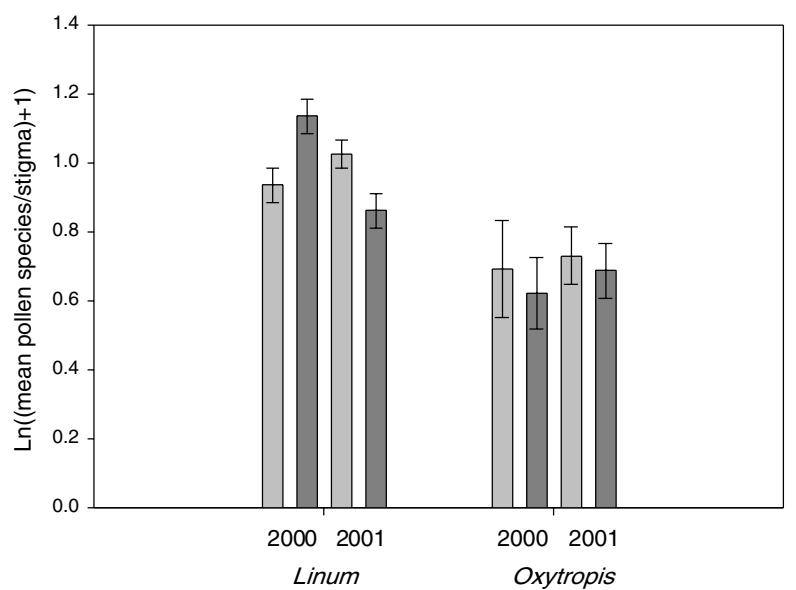

b. E. esula pollen grains/stigma

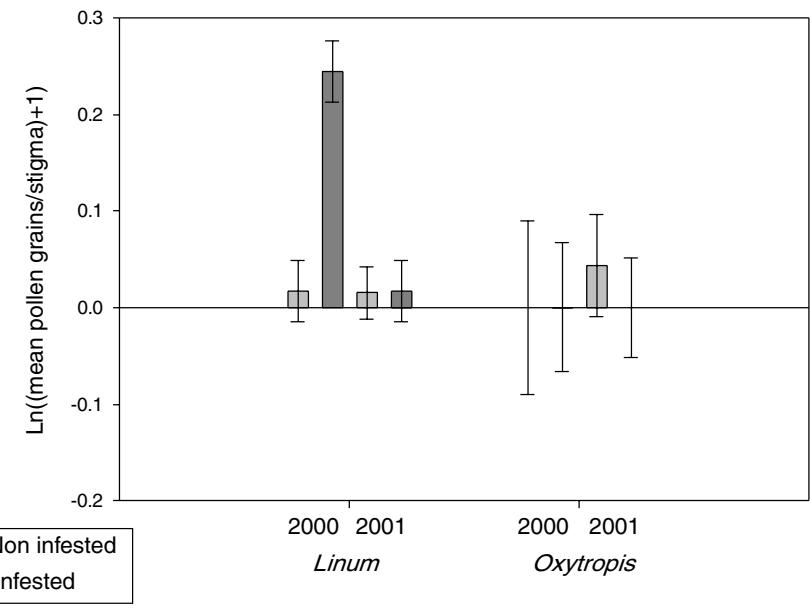

d. Proportion heterospecific pollen/stigma

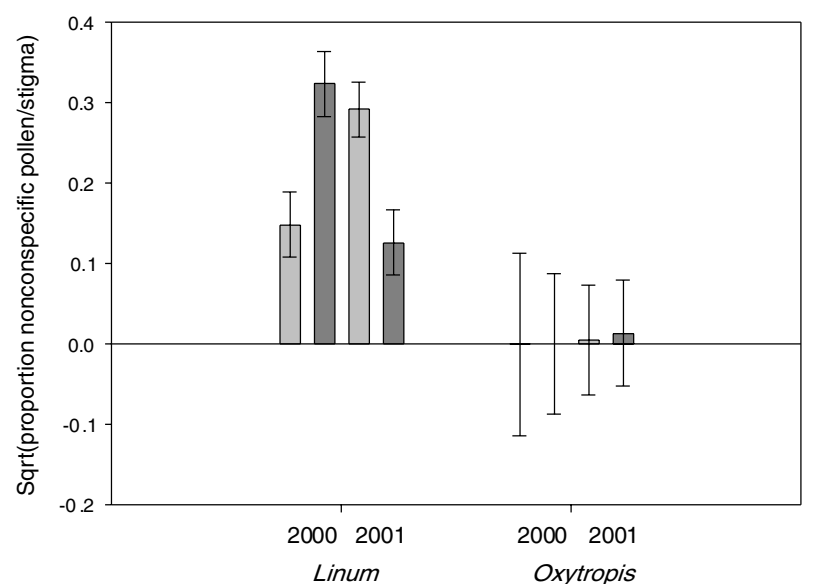

Fig. 2 - Pollen counts for stigmas collected from Linum lewisii and Oxytropis lambertii in 2000 and 2001. Shown are least square means of transformed $(\ln (n+1))$ counts; proportions were square-root transformed. (a) Conspecific pollen; (b) Euphorbia pollen; (c) number of pollen species; (d) proportion of heterospecific pollen.

Table 2 - ANOVA results for visitation by halictid bees to Linum lewisii, Campanula rotundifolia, Oxytropis lambertii and Euphorbia esula in 2001

\begin{tabular}{|c|c|c|c|c|c|}
\hline Target species & Effect & Num. DF & Den. DF & $F$ value & $\operatorname{Pr}>F$ \\
\hline \multirow[t]{4}{*}{ L. lewisii } & Infested & 1 & 58 & 8.85 & 0.0043 \\
\hline & Insect taxa & 4 & 231 & 19.5 & $<.0001$ \\
\hline & Infested $\times$ taxa & 4 & 231 & 2.47 & 0.0452 \\
\hline & Covariate & 1 & 231 & 6.89 & 0.0092 \\
\hline \multirow[t]{4}{*}{ C. rotundifolia } & Infested & 1 & 20 & 4.43 & 0.0481 \\
\hline & Insect taxa & 4 & 84 & 3.95 & 0.0055 \\
\hline & Infested $\times$ taxa & 4 & 84 & 2.12 & 0.0856 \\
\hline & Covariate & 1 & 84 & 1.06 & 0.3052 \\
\hline \multirow[t]{4}{*}{ O. lambertii } & Infested & 1 & 13 & 5.75 & 0.0322 \\
\hline & Insect taxa & 4 & 56 & 1.96 & 0.1126 \\
\hline & Infested $\times$ taxa & 4 & 56 & 1.96 & 0.1126 \\
\hline & Covariate & 1 & 56 & 5.48 & 0.0228 \\
\hline \multirow[t]{2}{*}{ E. esula } & Insect taxa & 4 & 236 & 2.66 & 0.0333 \\
\hline & Covariate & 1 & 236 & 0.01 & 0.9292 \\
\hline
\end{tabular}

The covariate is the number of flowers of the target species within the plot. 
Table 3 - Effects of infestation and native species from which the stigma was collected (stigma species) on pollen deposition on native stigmas

\begin{tabular}{|c|c|c|c|c|}
\hline \multirow[t]{2}{*}{ Variable } & \multicolumn{4}{|c|}{ Effect } \\
\hline & Infestation & Stigma sp. & Mean $^{a}$ & Std. error \\
\hline \multirow[t]{4}{*}{ Conspecific pollen } & No & & 4.3 & 0.16 \\
\hline & Yes & & 3.9 & 0.14 \\
\hline & & Linum & 2.6 & 0.095 \\
\hline & & Oxytropis & 5.5 & 0.19 \\
\hline \multirow[t]{2}{*}{ Number of pollen species } & & Linum & 0.99 & 0.024 \\
\hline & & Oxytropis & 0.68 & 0.052 \\
\hline \multirow[t]{2}{*}{ Proportion of heterospecific pollen } & & Linum & 0.22 & 0.020 \\
\hline & & Oxytropis & 0.0048 & 0.043 \\
\hline \multicolumn{5}{|c|}{ 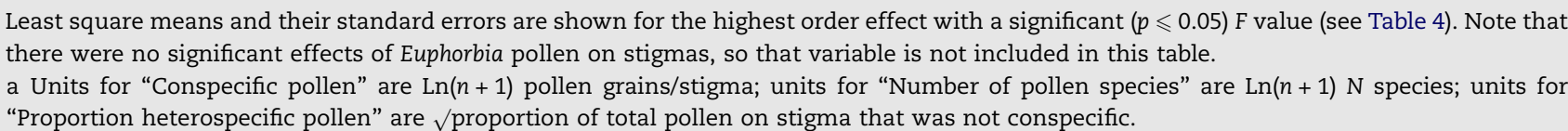 } \\
\hline
\end{tabular}

\section{Table 4 - ANOVA results for pollen counts on stigmas of Linum lewisii and Oxytropis lambertii (listed as "Stigma species") in} 2000 and 2001

\begin{tabular}{|c|c|c|c|c|c|}
\hline \multirow[t]{2}{*}{ Variable } & \multicolumn{5}{|c|}{ Type 3 tests of fixed effects } \\
\hline & Effect & Num. DF & Den. DF & $F$ & $P$ \\
\hline \multirow[t]{8}{*}{ Conspecific pollen } & Infestation & 1 & 101 & 4.85 & 0.0299 \\
\hline & Stigma sp. & 1 & 305 & 187.19 & $<.0001$ \\
\hline & Year & 1 & 305 & 3.42 & 0.0652 \\
\hline & Infestation $\times$ stigma sp. & 1 & 305 & 0.09 & 0.7696 \\
\hline & Infestation $\times$ year & 1 & 305 & 0.01 & 0.9243 \\
\hline & Stigma sp. $\times$ year & 1 & 305 & 3.03 & 0.0825 \\
\hline & Infestation $\times$ stigma sp. $\times$ year & 1 & 305 & 0.74 & 0.3919 \\
\hline & Covariate & 1 & 305 & 0.69 & 0.407 \\
\hline \multirow[t]{7}{*}{ Leafy spurge pollen } & Infestation & 1 & 342 & 1.59 & 0.2087 \\
\hline & Stigma sp. & 1 & 342 & 2.86 & 0.0919 \\
\hline & Year & 1 & 342 & 1.59 & 0.2086 \\
\hline & Infestation $\times$ stigma sp. & 1 & 342 & 3.41 & 0.0656 \\
\hline & Infestation $\times$ year & 1 & 342 & 3.33 & 0.0689 \\
\hline & Stigma sp. $\times$ year & 1 & 342 & 3.41 & 0.0658 \\
\hline & Infestation $\times$ stigma sp. $\times$ year & 1 & 342 & 1.53 & 0.2169 \\
\hline \multirow[t]{7}{*}{ Number of pollen species } & Infestation & 1 & 342 & 0.11 & 0.7382 \\
\hline & Stigma sp. & 1 & 342 & 28.39 & $<.0001$ \\
\hline & Year & 1 & 342 & 0.13 & 0.7238 \\
\hline & Infestation $\times$ stigma sp. & 1 & 342 & 0.41 & 0.52 \\
\hline & Infestation $\times$ year & 1 & 342 & 2.17 & 0.1419 \\
\hline & Stigma sp. $\times$ year & 1 & 342 & 1.54 & 0.2155 \\
\hline & Infestation $\times$ stigma sp. $\times$ year & 1 & 342 & 2.89 & 0.0899 \\
\hline \multirow[t]{7}{*}{ Proportion heterospecific pollen } & Infestation & 1 & 332 & 0.01 & 0.9225 \\
\hline & Stigma sp. & 1 & 332 & 21.17 & $<.0001$ \\
\hline & Year & 1 & 332 & 0.03 & 0.8542 \\
\hline & Infestation $\times$ stigma $\mathrm{sp}$. & 1 & 332 & 0 & 0.9954 \\
\hline & Infestation $\times$ year & 1 & 332 & 3.09 & 0.0795 \\
\hline & Stigma sp. $\times$ year & 1 & 332 & 0.15 & 0.7006 \\
\hline & Infestation $\times$ stigma sp. $\times$ year & 1 & 332 & 3.42 & 0.0652 \\
\hline
\end{tabular}

The covariate is the number of flowers of the target species within and adjacent to the plot.

in infested areas would likely put rare species within Euphorbia infestations at risk of pollen limitation, at least in some years.

The observational nature of this study imposes some limitations on our interpretation, in addition to the assessment of competition described above. There may have been qualities that varied systematically between infested and non-infested areas that were important to pollinators but that we did not measure, such as nest sites for ground-dwelling bees, or suitable woody vegetation for stem-nesters. 
a. Mean conspecific pollen grains on stigmas, 2001

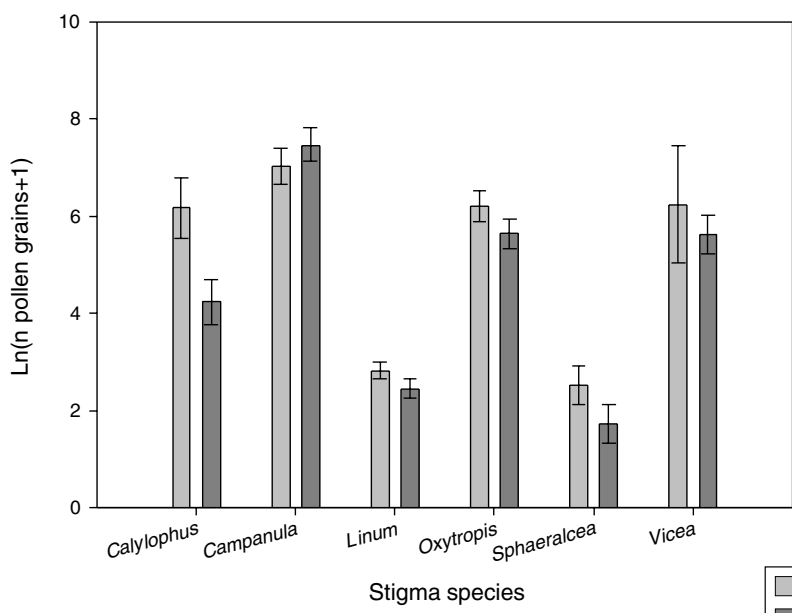

b. Mean leafy spurge pollen on stigmas, 2001

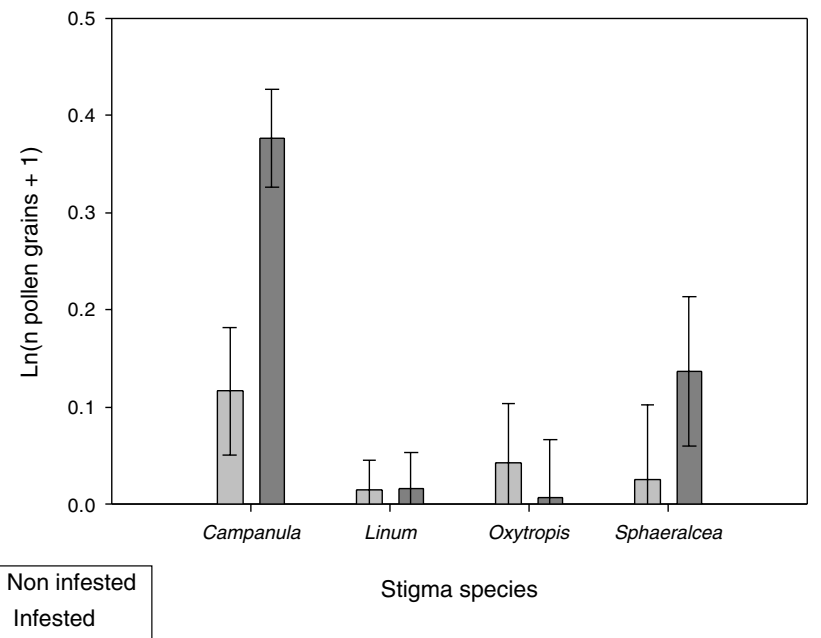

d. Proportion heterospecific pollen/stigma, 2001

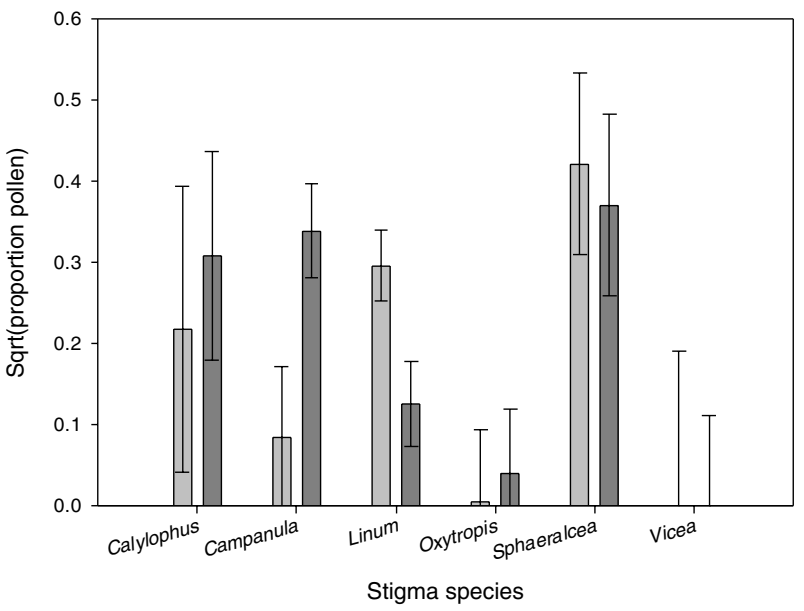

Fig. 3 - Pollen counts for stigmas collected from Calylophus, Campanula, Linum, Oxytropis, Sphaeralcea and Vicia in 2001. Shown are least square means of transformed $(\ln (n+1))$ counts; proportions were square-root transformed. (a) Conspecific pollen; (b) Euphorbia pollen; (c) number of pollen species; (d) proportion of heterospecific pollen.

\begin{tabular}{|c|c|c|c|c|c|}
\hline \multirow[t]{2}{*}{ Response variable } & \multicolumn{5}{|c|}{ Type 3 tests of fixed effects } \\
\hline & Effect & Num. DF & Den. DF & F & $P$ \\
\hline \multirow[t]{4}{*}{ Conspecific pollen } & Infestation & 1 & 92 & 4.78 & 0.0314 \\
\hline & Stigma sp. & 5 & 275 & 81.88 & $<.0001$ \\
\hline & Infestation $\times$ stigma sp. & 5 & 275 & 1.48 & 0.1963 \\
\hline & Covariate & 1 & 275 & 0.72 & 0.3961 \\
\hline \multirow[t]{3}{*}{ Leafy spurge pollen } & Infestation & 1 & 257 & 3.99 & 0.0468 \\
\hline & Stigma sp. & 3 & 257 & 8.14 & $<.0001$ \\
\hline & Infestation $\times$ stigma $\mathrm{sp}$. & 3 & 257 & 2.94 & 0.0336 \\
\hline \multirow[t]{3}{*}{ Number of pollen species } & Infestation & 1 & 291 & 7.37 & 0.007 \\
\hline & Stigma sp. & 5 & 291 & 7.46 & $<.0001$ \\
\hline & Infestation $\times$ stigma sp. & 5 & 291 & 1.18 & 0.3171 \\
\hline \multirow[t]{3}{*}{ Proportion heterospecific pollen } & Infestation & 1 & 280 & 0.17 & 0.684 \\
\hline & Stigma sp. & 5 & 280 & 3.73 & 0.0027 \\
\hline & Infestation $\times$ stigma sp. & 5 & 280 & 2.46 & 0.0332 \\
\hline
\end{tabular}




\subsection{Improper pollen transfer}

In addition to influencing visitation rates and deposition of conspecific pollen, native plants within infestations may experience increased deposition of heterospecific pollen. Empirical studies have generally found little invasive pollen on native stigmas (Aigner, 2004; Moragues and Traveset, 2005) and our study is no exception. We found only very small amounts of Euphorbia pollen on native stigmas (no species had a back-transformed mean $>0.5$ grains/stigma), although the amounts varied significantly among native species; Campanula and Linum had greater amounts of Euphorbia pollen than other species in at least one year of the study. Zygomorphic species Oxytropis and Vicia were largely immune from Euphorbia pollen, as was actinomorphic species Calylophus: none was ever found on Vicia or Calylophus stigmas. Although pollinators may be more likely to act as generalists among morphologically similar species (Kunin, 1993, 1997), we found no evidence that species more similar to Euphorbia, in terms of flower shape (e.g., Linum, Sphaeralcia) or color (Calylophus) received more Euphorbia pollen than did dissimilar flowers (e.g., Campanula, Oxytropis, Vicia). Pollinators may discern patterns of flower similarities that differ from our broad categorizations of symmetry and visible color, however.

If Euphorbia infestations attract greater numbers of generalist pollinators, we would expect higher numbers of pollen species and greater proportions of heterospecific pollen on native species within these infestations. In general, we found fewer species of pollen on stigmas from infested sites and inconsistent differences in proportions of heterospecific pollen, suggesting that, if Euphorbia is attracting generalist pollinators, this does not translate into IPT for native species. Although contrary to our expectation, this result may reflect an indirect effect of leafy spurge infestation, in that species richness has been found to be lower within dense infestations (Belcher (1989); Larson, unpublished data). If fewer plant species exist within the foraging area of pollinators, fewer pollen species would be available for deposition on stigmas.

The variability we found in heterospecific pollen on stigmas once again emphasizes our limited ability to generalize about effects of infestation. Given the relatively low amounts of Euphorbia pollen and proportions of heterospecific pollen (ranging from a back-transformed mean of $<1 \%$ for Vicia and Oxytropis to $14-18 \%$ for Sphaeralcea), the differences we found may have little biological significance for most species. However, we did find that introduction of Euphorbia pollen onto hand pollinated Linum flowers resulted in significantly lower seed set than that found for flowers on the same plant that were only hand pollinated (least square means $=5 \pm 0.84$ and $9 \pm 0.64$ for spurge introduced vs. no spurge on fully pollinated flowers, $F=7.34$, $\mathrm{df}=2,8, p=0.0155$; Larson, unpublished data), leaving open the possibility that small quantities of Euphorbia pollen may have fitness effects.

Chittka and Schürkens (2001) proposed that competition between native and invasive plants may occur at substantially greater distances than previously thought, due to the distances traveled by pollinators. Our results support that proposition. Approximately $10 \%$ of the flowers we sampled had Euphorbia pollen. The amount of Euphorbia pollen on stigmas varied only slightly between infested and non-infested sites, thus indicating that the invasive pollen is transported, at least occasionally, $>100 \mathrm{~m}$, while interspecific competition for light and nutrients typically occurs within a few $\mathrm{cm}$ of the plant.

\subsection{Management implications}

The primary effects of Euphorbia infestation on pollination of native plants were a decline in conspecific pollen deposited on stigmas in both years and in visitation by bees, especially Halictus spp. and Dialictus spp. in the family Halictidae, in one of the two years studied. Given that we detected declines in conspecific pollen in species that are relatively common, the potential for significant pollen shortfalls in rare species is high. Managers need to be aware of the danger of pollen limitation, especially in rare or uncommon plant species. Clonal or long-lived species may persist for considerable periods of time in the absence of effective pollination, leading to what Johnson and Steiner (2000) have called "an insidious form of delayed extinction". Most land managers are aware of the locations of species of concern on their properties. We would encourage them to monitor seed set (which is considerably easier to accomplish than are studies of pollination) of the insect-pollinated species if significant encroachment of invasive species is noted. If reductions in seed set are noted, this should trigger more extensive studies of potential mechanisms, including pollen limitation and IPT.

Of equal importance is the observation that native halictid bees are less frequent visitors in infested areas in some years. Despite a general increase in visits by halictids in noninfested areas between 2000 and 2001, visits in infested areas were down substantially over the same time period. Our results add to recent concern over the general decline in pollinators (Kearns et al., 1998) and accentuate the need to understand the role that invasive species play at all levels of the ecosystems they invade. Because halictids are notoriously difficult to identify, they present a special challenge to land managers who wish to monitor their populations. Additional research to determine the reasons for fewer halictids within Euphorbia infestations might suggest indirect methods of assessing risk to halictid populations that would be more accessible to land managers than direct monitoring of the bee populations.

Finally, the variability we observed between years requires further investigation. We found no obvious correlations with local differences in temperature or precipitation between the two years, so we cannot say what might have caused the variability we observed. Managers will need to know how frequently to expect effects of infestation to occur and to know if concurrency with other environmental fluctuations might exacerbate effects of infestation.

\section{Acknowledgments}

We gratefully acknowledge field assistance provided by A. Haas, G. Hanley, D. Lang, J. Larson, J. Plummer, P. Scherr and 
L. Van Riper and pollen counting by J. Larson and K. Jacobson. D. Yanega identified voucher specimens of bees. We are grateful for comments on a previous draft by S. Huerd, N. Jordan, R. Mitchell, C. Reed, N. Waser, two anonymous reviewers, and members of the Jordan and Larson lab groups, that significantly improved the manuscript. We thank staff at Theodore Roosevelt National Park who provided logistical support for this study and for many others over the years. Funding was provided by the US Geological Survey's Park Oriented Biological Support Program and Northern Prairie Wildlife Research Center.

\section{Appendix A}

Visitation by insects to Linum lewisii, Campanula rotundifolia, Oxytropis lambertii and Euphorbia esula. Part a includes all insect visitor taxa across the two years of the study. Note that "Bees" exclude bumblebees, which are listed as "Bombus". Part $b$ includes only those bees in the family Halictidae in 2001. Least square means $(\ln (n+1)$ pollen grains/stigma) and their standard errors are shown for the highest order effect with a significant $(p \leqslant 0.05) F$ value.

\begin{tabular}{|c|c|c|c|c|c|}
\hline $\begin{array}{l}\text { Target } \\
\text { species }\end{array}$ & Infested & $\begin{array}{c}\text { Insect } \\
\text { taxa }\end{array}$ & Year & $\begin{array}{c}\text { Visits/20 } \\
\text { min }\end{array}$ & $\begin{array}{l}\text { Std. } \\
\text { error }\end{array}$ \\
\hline \multicolumn{6}{|l|}{ Part a } \\
\hline \multirow[t]{20}{*}{ L. lewisii } & no & Bees & 2000 & 0.74 & 0.10 \\
\hline & yes & Bees & 2000 & 0.83 & 0.11 \\
\hline & no & Bees & 2001 & 1.22 & 0.08 \\
\hline & yes & Bees & 2001 & 0.59 & 0.09 \\
\hline & no & Bombus & 2000 & 0.02 & 0.10 \\
\hline & yes & Bombus & 2000 & 0.07 & 0.11 \\
\hline & no & Bombus & 2001 & 0.04 & 0.08 \\
\hline & yes & Bombus & 2001 & -0.03 & 0.09 \\
\hline & no & Diptera & 2000 & 0.40 & 0.10 \\
\hline & yes & Diptera & 2000 & 0.20 & 0.11 \\
\hline & no & Diptera & 2001 & 0.55 & 0.08 \\
\hline & yes & Diptera & 2001 & 0.58 & 0.09 \\
\hline & no & Lepidoptera & 2000 & 0.18 & 0.10 \\
\hline & yes & Lepidoptera & 2000 & 0.05 & 0.11 \\
\hline & no & Lepidoptera & 2001 & 0.08 & 0.08 \\
\hline & yes & Lepidoptera & 2001 & 0.01 & 0.09 \\
\hline & no & Wasps & 2000 & 0.03 & 0.10 \\
\hline & yes & Wasps & 2000 & 0.00 & 0.11 \\
\hline & no & Wasps & 2001 & 0.06 & 0.08 \\
\hline & yes & Wasps & 2001 & 0.03 & 0.09 \\
\hline \multirow[t]{10}{*}{ C. rotundifolia } & no & Bees & 2000 & 0.56 & 0.20 \\
\hline & yes & Bees & 2000 & 1.38 & 0.12 \\
\hline & no & Bees & 2001 & 1.00 & 0.11 \\
\hline & yes & Bees & 2001 & 0.27 & 0.12 \\
\hline & no & Bombus & 2000 & 0.00 & 0.20 \\
\hline & yes & Bombus & 2000 & 0.11 & 0.12 \\
\hline & no & Bombus & 2001 & 0.06 & 0.11 \\
\hline & yes & Bombus & 2001 & 0.00 & 0.12 \\
\hline & no & Diptera & 2000 & 0.00 & 0.20 \\
\hline & yes & Diptera & 2000 & 0.04 & 0.12 \\
\hline
\end{tabular}

\begin{tabular}{|c|c|c|c|c|c|}
\hline $\begin{array}{l}\text { Target } \\
\text { species }\end{array}$ & Infested & $\begin{array}{l}\text { Insect } \\
\text { taxa }\end{array}$ & Year & $\begin{array}{l}\text { Visits/ } \\
20 \mathrm{~min}\end{array}$ & $\begin{array}{l}\text { Std. } \\
\text { error }\end{array}$ \\
\hline & no & Diptera & 2001 & 0.17 & 0.11 \\
\hline & yes & Diptera & 2001 & 0.29 & 0.12 \\
\hline & no & Lepidoptera & 2000 & 0.00 & 0.20 \\
\hline & yes & Lepidoptera & 2000 & 0.00 & 0.12 \\
\hline & no & Lepidoptera & 2001 & 0.00 & 0.11 \\
\hline & yes & Lepidoptera & 2001 & 0.00 & 0.12 \\
\hline & no & Wasps & 2000 & 0.00 & 0.20 \\
\hline & yes & Wasps & 2000 & 0.00 & 0.12 \\
\hline & no & Wasps & 2001 & 0.00 & 0.11 \\
\hline & yes & Wasps & 2001 & 0.00 & 0.12 \\
\hline \multirow[t]{10}{*}{ O. lambertii } & no & Bees & 2000 & 0.43 & 0.08 \\
\hline & yes & Bees & 2001 & 0.30 & 0.11 \\
\hline & no & Bombus & 2000 & 0.18 & 0.08 \\
\hline & yes & Bombus & 2001 & 0.09 & 0.11 \\
\hline & no & Diptera & 2000 & 0.03 & 0.08 \\
\hline & yes & Diptera & 2001 & 0.33 & 0.11 \\
\hline & no & Lepidoptera & 2000 & 0.27 & 0.08 \\
\hline & yes & Lepidoptera & 2001 & 0.05 & 0.11 \\
\hline & no & Wasps & 2000 & -0.01 & 0.08 \\
\hline & yes & Wasps & 2001 & 0.09 & 0.11 \\
\hline \multirow[t]{5}{*}{ E. esula } & yes & Bees & & 0.22 & 0.05 \\
\hline & yes & Bombus & & 0.00 & 0.05 \\
\hline & yes & Diptera & & 0.73 & 0.05 \\
\hline & yes & Lepidoptera & & 0.01 & 0.05 \\
\hline & yes & Wasps & & 0.16 & 0.05 \\
\hline $\begin{array}{l}\text { Target } \\
\text { species }\end{array}$ & Infested & $\begin{array}{c}\text { Insect } \\
\text { taxa }\end{array}$ & $\begin{array}{l}\text { Visits/20 } \\
\text { min }\end{array}$ & $\begin{array}{l}\text { Std. } \\
\text { error }\end{array}$ & \\
\hline \multicolumn{6}{|l|}{ Part $b$} \\
\hline \multirow[t]{10}{*}{ L. lewisii } & No & Agapostemon & 0.08 & 0.10 & \\
\hline & Yes & Agapostemon & -0.01 & 0.11 & \\
\hline & No & Dialictus & 0.71 & 0.10 & \\
\hline & Yes & Dialictus & 0.29 & 0.11 & \\
\hline & No & Halictid sp. & 1.01 & 0.10 & \\
\hline & Yes & Halictid sp. & 0.45 & 0.11 & \\
\hline & No & Halictus & 0.33 & 0.10 & \\
\hline & Yes & Halictus & 0.06 & 0.11 & \\
\hline & No & Lasioglossum & 0.13 & 0.10 & \\
\hline & Yes & Lasioglossum & 0.06 & 0.11 & \\
\hline \multirow[t]{7}{*}{ C. rotundifolia } & No & & 0.39 & 0.10 & \\
\hline & Yes & & 0.07 & 0.11 & \\
\hline & & Agapostemon & 0.10 & 0.11 & \\
\hline & & Dialictus & 0.36 & 0.11 & \\
\hline & & Halictid sp. & 0.48 & 0.11 & \\
\hline & & Halictus & 0.14 & 0.11 & \\
\hline & & Lasioglossum & 0.06 & 0.11 & \\
\hline \multirow[t]{2}{*}{ O. lambertii } & No & & 0.15 & 0.04 & \\
\hline & Yes & & 0.00 & 0.04 & \\
\hline \multirow[t]{5}{*}{ E. esula } & Yes & Agapostemon & 0.07 & 0.04 & \\
\hline & Yes & Dialictus & 0.10 & 0.04 & \\
\hline & Yes & Halictid sp. & 0.13 & 0.04 & \\
\hline & Yes & Halictus & 0.02 & 0.04 & \\
\hline & Yes & Lasioglossum & 0.00 & 0.04 & \\
\hline
\end{tabular}




\section{R E F E R E N C E S}

Aigner, P.A., 2004. Ecological and genetic effects on demographic processes: pollination, clonality and seed production in Dithyrea maritima. Biological Conservation 116, 27-34.

Bangsund, D.A., Leitch, J.A., Leistritz, F.L., 1996. Economics of herbicide control of leafy spurge (Euphorbia esula L). Journal of Agricultural and Resource Economics 21, 381-395.

Bangsund, D.A., Leistritz, F.L., Leitch, J.A., 1999. Assessing economic impacts of biological control of weeds: The case of leafy spurge in the northern Great Plains of the United States. Journal of Environmental Management 56, 35-43.

Belcher, J.W., Wilson, S.D., 1989. Leafy spurge and the species composition of a mixed-grass prairie. Journal of Range Management 42, 172-175.

Brown, B.J., Mitchell, R.J., 2001. Competition for pollination: effects of pollen of an invasive plant on seed set of a native congener. Oecologia 129, 43-49.

Brown, B.J., Mitchell, R.J., Graham, S.A., 2002. Competition for pollination between an invasive species (purple loosestrife) and a native congener. Ecology 83, 2328-2336.

Chittka, L., Schürkens, S., 2001. Successful invasion of a floral market - an exotic Asian plant has moved in on Europe's river-banks by bribing pollinators. Nature 411, 653 .

Feldman, T.S., Morris, W.F., Wilson, W.G., 2004. When can two plant species facilitate each other's pollination? Oikos 105, 197-207.

Fishbein, M., Venable, D.L., 1996. Diversity and temporal change in the effective pollinators of Asclepias tuberosa. Ecology 77, 1061-1073.

Gegear, R.J., Laverty, T.M., 1998. How many flower types can bumble bees work at the same time? Canadian Journal of Zoology 76, 1358-1365.

Gegear, R.J., Laverty, T.M., 2004. Effect of a colour dimorphism on the flower constancy of honey bees and bumble bees. Canadian Journal of Zoology 82, 587-593.

Herrera, C.M., 1988. Variation in mutualisms: the spatio-temporal mosaic of a pollinator assemblage. Biological Journal of the Linnean Society 35, 95-125.

Herrera, C.M., 1995. Microclimate and individual variation in pollinators: flowering plants are more than their flowers. Ecology 76, 1516-1524.

Johnson, S.D., Steiner, K.E., 2000. Generalization versus specialization in plant pollination systems. Trends in Ecology and Evolution 15, 140-143.

Kearns, C.A., Inouye, D.W., 1993. Techniques for Pollination Biologists. University Press of Colorado, Niwot, Colorado.

Kearns, C.A., Inouye, D.W., 1994. Fly pollination of Linum lewisii (Linaceae). American Journal of Botany 81, 1091-1095.

Kearns, C.A., Inouye, D.W., Waser, N.M., 1998. Endangered mutualisms: The conservation of plant-pollinator interactions. Annual Review of Ecology and Systematics 29, 83-112.
Kunin, W.E., 1993. Sex and the single mustard: population density and pollinator behavior effects on seed-set. Ecology 74, 2145-2160.

Kunin, W.E., 1997. Population size and density effects in pollination - pollinator foraging and plant reproductive success in experimental arrays of Brassica kaber. Journal of Ecology 85, 225-234.

Larson, D.L., Anderson, P.J., Newton, W., 2001. Alien plant invasion in mixed-grass prairie: effects of vegetation type and anthropogenic disturbance. Ecological Applications 11, 128-141.

Lau, J.A., Galloway, L.F., 2004. Effects of low-efficiency pollinators on plant fitness and floral trait evolution in Campanula americana (Campanulaceae). Oecologia 141, 577-583.

McLernon, S.M., Murphy, S.D., Aarssen, L.W., 1996. Heterospecific pollen transfer between sympatric species in a midsuccessional old-field community. American Journal of Botany 83, 1168-1174.

Memmott, J., Waser, N.M., 2002. Integration of alien plants into a native flower-pollinator visitation web. Proceedings of the Royal Society of London Series B-Biological Sciences 269, 2395-2399.

Mitchell, R.J., 1997. Effects of pollination intensity on Lesquerella fendleri seed set - variation among plants. Oecologia 109, 382-388.

Moragues, E., Traveset, A., 2005. Effect of Carpobrotus spp. on the pollination success of native plant species of the Balearic Islands. Biological Conservation 122, 611-619.

Palmer, T.M., Stanton, M.L., Young, T.P., 2003. Competition and coexistence: exploring mechanisms that restrict and maintain diversity within mutualist guilds. American Naturalist 162, S63-S79.

Price, M.V., Waser, N.M., Irwin, R.E., Campbell, D.R., Brody, A.K., 2005. Temporal and spatial variation in pollination of a montane herb: A seven-year study. Ecology 86, 2106-2116.

Rathcke, B., 1983. Competition and facilitation among plants for pollination. In: Real, L. (Ed.), Pollination Biology. Academic Press, Inc., Orlando, FL, pp. 305-329.

Roubik, D.W., 2001. Ups and downs in pollinator populations: when is there a decline? Conservation Ecology, 5.

SAS Institute, Inc., 1999. SAS OnlineDoc ${ }^{\circledR}$, Version 8. SAS Institute, Inc., Cary, NC.

Selleck, G.W., Coupland, R.T., Frankton, C., 1962. Leafy spurge in Saskatchewan. Ecological Monographs 32, 1-29.

Spira, T.P., 2001. Plant-pollinator interactions: A threatened mutualism with implications for the ecology and management of rare plants. Natural Areas Journal 21, 78-88.

Trammell, M.A., Butler, J.L., 1995. Effects of exotic plants on native ungulate use of habitat. Journal of Wildlife Management 59, 808-816.

Waser, N.M., 1978. Interspecific pollen transfer and competition between co-occurring plant species. Oecologia 36, 223-236.

Waser, N.M., Chittka, L., Price, M.V., Williams, N.M., Ollerton, J., 1996. Generalization in pollination systems, and why it matters. Ecology 77, 1043-1060. 